Nig. J. Pure \& Appl. Sci. Vol. 33 (Issue 1, 2020)
eISSN 2756-4045
Life Sciences, Univ. of Ilorin, Nigeria
www.njpas.com.ng

doi: http://dx.doi.org/10.48198/NJPAS/19.B23

\title{
ASSESSING THE AWARENESS, KNOWLEDGE, ATTITUDE AND PRACTICE OF THE INHABITANTS CLOSE TO A SOLID WASTE DUMPSITE TOWARDS HUMAN INTESTINAL PARASITE IN ABA MUNICIPAL, ABIA STATE, NIGERIA
}

*AMADI, A. N. C., CHUKWUEMEKA, B. C. and OBETEN, P. I.

Department of Zoology and Environmental Biology, College of Natural Sciences and Environmental Biology Michael Okpara University of Agriculture, Umudike.

\begin{abstract}
Solid waste management has remained a major problem in most developing nations, Nigeria inclusive thus posing serious public health issues to those living around such solid waste dumpsites. This study was conducted in Aba dumpsite to investigate the residents' awareness, knowledge, attitude and practice on the solid waste disposal practices and its effect consequences towards human intestinal parasite. A structured questionnaire was administered to elicit the resident responses on their knowledge, attitude and practices towards solid waste disposal and human intestinal parasites. In the study, majority of the residents' were male 296(70.0\%), and $127(30.0 \%)$ were females. Most of them 103(24.3\%) were of the age group $11-20$ years, then 93(22.0\%) $0-10$ years, 84(19.9\%) 21 - 30 years, 75(17.7\%) 31-40years, 41(9.7\%) and 27(6.4\%) were 51 and above. Majority $155(36.6 \%)$ of the residents' attended Primary education, 123(29.1\%) Secondary education, 78(18.4\%) Polytechnics, and 41(9.7\%) University while 26(6.1\%) had no educational qualification. Most of the residents $121(28.6 \%)$ have stayed less than 9 years while $85(20.1 \%)$ have stayed less than 6 years. Most of the respondents $159(37.6 \%)$ resides closer to the dumpsite while 37(8.7\%) are farther apart. Analysis of the questionnaire revealed that majority $(87.5 \%)$ of the residents are aware that they are at risk of contracting human intestinal parasite for living close to the site. Most 365(86.3\%) know that intestinal parasites can be contracted through poor hygiene. Majority 197(46.6\%) dispose waste at the dumpsite daily. Most of the respondents 216(51.1\%) disagreed to the fact that wastes at the site are managed regularly. Majority 329(77.8\%) agreed that one can get the parasites from dumpsite. The dumpsite workers strongly agreed 11(78.6\%) that increase in industrialization and consumption of fresh raw was the major factor militating them against their level of efficiency in the management of waste at the dumpsite. Wastes not properly managed have a negative impact on health, environment and aesthetic values. A well-planned waste management and proper health education programme for residents living around the dumpsite will go a long way in reducing the potential of epidemic risks posed by dumpsites in Aba municipal.
\end{abstract}

Keywords: Residents’ Awareness, knowledge and Practice, Solid Waste Dumpsite, Health Implications.

\section{Introduction}

Human activities produce waste materials which are often discarded because they are considered useless. These wastes are mainly solid, and the word waste places them in the class of useless and unwanted. However, some of these wastes can become of great resource if they are reused or 
recycled. They can serve as a resource for further industrial production or energy generation when managed properly. (Tchobanoglous et al., 2007). Waste has been defined by the Glossary of Environment Statistics (2001) as a material which Page | 3586 is a prime product (i.e. products produced for the market) in which the initial user has no need for further usage with regards to him/her own purposes of production, transformation and consumption and of which him/she wants to discard. These wastes can be produced during the extraction and processing of raw materials into intermediate and final products and other human activities. According to the United State Environmental Protection Agency (USEPA, 2013), solid waste are referred to as any useless, unwanted and discarded materials produced during human activities which cannot be discarded through the sewer pipe. Solid waste accumulates in the environment as a result of its sticky and non-free flowing nature in the form of refuse dumps.

Solid waste as stated by Ovu (2008) comprises of all solid products that are made up of wholly or partly of materials such as garbage, rubbish, litter, cleanings, sweepings, trash, industrial solid waste or domestic solid waste including organic wastes and residues of animals, meat, animal excreta or carcasses of animals; grains or fish; fruit, vegetables, rubbish including, wood, leaves, vegetables, tree trimmings, dead trees and shrubs, branches, sawdust, shavings, grass, paper products, straws, rags, clothing and other combustibles; waste mater composed of soil, clay, sand, earth, gravel, fill, stones, bricks, plaster, glass, glassware, crockery, ashes, cinders, shells, metals and other non-combustibles; waste debris that results from construction, repair or alteration of structures or building, demolition,; accumulated waste material made of cans, containers, tires, junk, vehicle parts or other substance which may become a nuisance (Ovu, 2008).

Solid waste disposal and management has been a global issue with regards to environmental contamination, social inclusion, and economic sustainability (Gupta, et al., 2015), and this needs an integrated assessments and holistic strategies to solve this problem (Bling et al., 2016). Waste management in developing and transition countries appears to be battle against the harmful consequences of unsystematic refuse collection and disposal and the actualization of clean healthy environment. It has become a common sight in Nigeria today to see heaps of festering refuse dumps in our urban and commercial cities (Adewole, 2009) These wastes are aesthetically unpleasant, constitute eyesores, generates unpleasant odours especially when the activities of putrefying bacteria act on their organic compositions (Onyido et al., 2009). Sule (2004) stated that most of the Nigerians life styles today is a reflection of their consumption and solid waste generation pattern they adopted. This is evident in their attitudinal problem of indiscriminate refuse disposal in visually all sides of residential apartments, highways, corners of major and minor streets, drains and undeveloped plots of land by many households (Akinwale, 2005). These indiscriminate refuse dumps support the breeding of biological vectors such as mosquitoes and rodents which enhances disease transmission such as malaria, diarrhea, and Lassa fever which are of public health concern (Sule, 2004; Bassavanthappa, 2008; Onyido et al., 2009).

It has become a common sight in Nigeria today to see heaps of festering refuse dumps in our urban and commercial cities (Adewole, 2009). These wastes are aesthetically unpleasant, constitute eyesores, generates unpleasant odours especially when the activities of putrefying bacteria acts on their organic compositions (Onyido et al., 2009). Sule (2004) stated that most of the Nigerians life styles today is a reflection of their consumption and solid waste generation pattern they adopted. This is evident in their attitudinal problem of indiscriminate refuse disposal in visually all sides of residential apartments, highways, corners of major and minor streets, drains and undeveloped 
plots of land by many households (Akinwale, 2005). These indiscriminate refuse dumps support the breeding of biological vectors such as mosquitoes and rodents which enhances disease transmission such as malaria, diarrhea, and Lassa

Page | 3587 fever which are of public health concern (Sule, 2004; Bassavanthappa, 2008; Onyido et al., 2009). According to Drew et al. (2007) a designated place set aside for waste disposal and management is known as, municipal waste dumpling sites. Depending on a city's level of waste management, waste can be discarded in an indiscriminately, separated for recycling purposes, or simply burnt. Poor waste management poses a great challenge to the health of the city residents, particularly those living close to a solid waste dumpsite due to potential of waste to pollute the water, food source, air, land and vegetation (Lou and Nair, 2009). Poor waste disposal and handling therefore leads to environmental degradation, destruction of the ecosystem and poses great risks to public health. Access to improved sanitation promotes human health, dignity, security and well-being of the people (Sida, 2012). Similarly, poor sanitation is an indicators of health problems (Prasad, 2013). Due to rapid urbanization, environmental sanitation problems are at the heart of the woes of African countries. The rapid increase of urban population brings about a rising demand for food and other essential services which in turn increases waste generation daily by each household (Zhu et al., 2008).

Refuse, soil, animal waste and sewage sludge are common sources of manure, used to fertilize agriculture fields (Okoronkwo and Onwuliri, 1998). Studies carried out by Adeyeba and Akinbo (2002) revealed the incidence and distribution of many pathogenic intestinal parasites and bacterial agents from refuse that affects both man and animals.

Intestinal parasites are life threatening in many communities and are of a major international health concern (Liza et al. 2004) and it has been shown that refuse dumps are significant source of transmission for intestinal parasitic infection in Kampala, Uganda and Jos, Nigeria (Okoronkwo and Onwuliri, 1998).

Cletus, et. al., 2015The implications of ineffective waste collection and poor management of waste is uncountable. Insufficient collection and poor disposal practices leads to serious health related problems to both human and the environment (Loboka et al., 2013). In Sub-Sahara Africa for instance, poor disposal practices have aggravated health related problems (Zhu et al., 2008). Emily (2004) asserted that when waste is not collected, it results to the development of unsanitary conditions and thus poses environmental and human health risks.

Modernization and progress in urbanization and development of our environment have its share of disadvantages and its main aspects of concern is on pollution of the environment (land, air, and water). With rapid increase in population which also result to increase in food consumption and other necessities of life, there is an increase in the amount of waste generated on daily basis by each household. These wastes are collected by the area municipalities at the municipal waste collection centers to be thrown into the landfills and dumpsites. However, not all of this waste gets collected and transported to the final dumpsites, either due to resource crunch or inefficient infrastructure. Improper waste management and disposal at this stage causes serious health problems to the surrounding environment.

Solid waste therefore, that is not properly managed, is a serious health hazard and lead to the spread of infectious diseases. Thus, this study aims at assessing the awareness, attitude, knowledge and practice of residents close to the solid waste dumpsite and its influence in the distribution of intestinal parasite. 


\section{Materials and Methods Study Area}

The study was conducted in Aba municipal, Abia State, Eastern Nigeria. Aba is located on coPage | 3588 ordinates $5^{0} 10^{\prime} \mathrm{N}, 7^{0} 19^{\prime}-23^{\prime} \mathrm{E}$ (Obianyo and Ugwu,2018). The vegetation is typical of the tropical rain forest with a relief of about $0-200 \mathrm{ft}(0-$ $61 \mathrm{~m})$ above the sea level. The mean annual temperature ranges from $25.5^{\circ} \mathrm{C}$ to $26.5^{\circ} \mathrm{C}$ (Etusim et.al., 2013). The population as of 2016 was estimated to be 2,534,265 (Abia-Population, 2016) Aba was selected for the study because it is a big city and a big trading centre in Abia State. Aba is divided into three local government areas namely; Aba South, Aba North and Osisioma. Aba south is considered to be the commercial hub of the city as most of the commercial activities take place in that part of the city. The inhabitants of Aba metropolis are predominantly traders, with a few civil servants and others who work in Industries. There are also owners of small and medium scale enterprise. It is notorious for its high record of improper waste disposal. It is a common sight to see waste littered in the streets and heaps of refuse in some corners of the street. Aba is a major urban settlement and commercial centre in the region that is surrounded by small villages and towns. The indigenous people of Aba are the Ngwa. Aba is well known for its craftsmen.

\section{Ethical Consideration}

This work was approved by Abia State Ministry of Health (AB/MH/AD/904/T.159), Abia State Ministry of Environment (MENV/AD/63/T/28) and Aba South Local Government Environmental Health (ABLG/ENV./001).

\section{Data Collection}

Data was collected from students, workers (which include teachers, Dumpsite workers, eatery owners and other petty traders/shop owners) who are closer to the dumpsites, informal recyclers (Scavengers) and residents living close to the dumpsite through structured questionnaire. The objective of the questionnaire survey method was to obtain views and ideas of different people living, working and schooling near the dumpsite concerning solid waste disposal. The following aspects were considered in the survey; disposal methods, awareness of the health implications with regards to intestinal parasites, satisfaction with the management practices, their length of stay in the dumpsite area and distance of their houses or work place from the dumpsites.

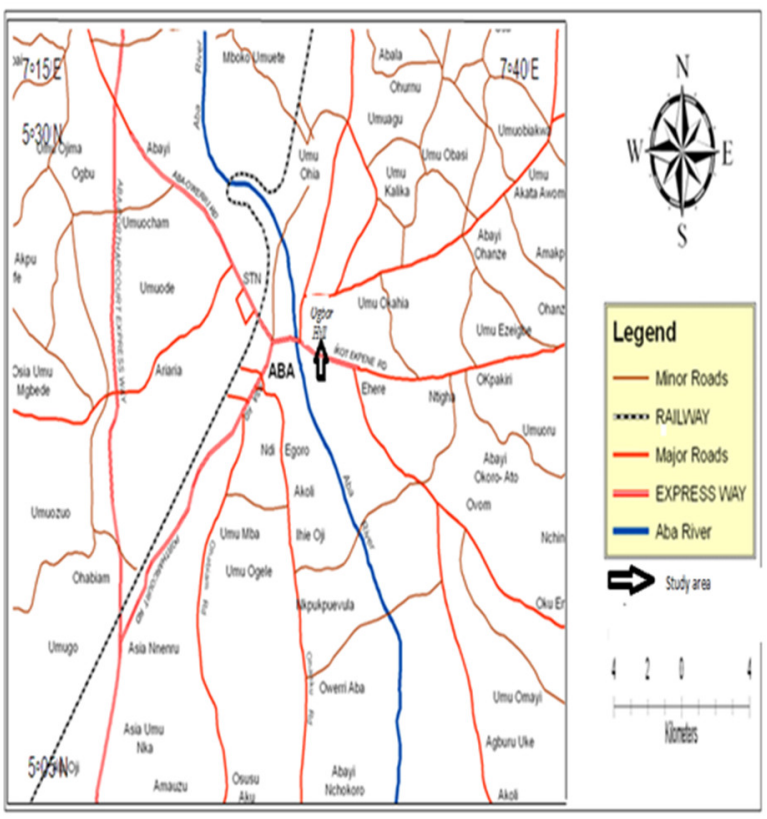

Fig. 1: Location map of Aba showing Ogbor hill, the study area (Amadi, 2012).

\section{Data Analysis}

PATS version 3.1 statistical package was used for the data analysis.

\section{Results}

Out of the 471 residents contacted, majority of the respondents 296(70.0\%) were males and $127(30.0 \%)$ were females. Most 103(24.3\%) of the respondents were $11-20$ years old, $0-10$ years old 93(22.0\%), 21 - 30 years old 84(19.9\%), $31-40$ years old 75(17.7\%), $41-50$ years old $41(9.7 \%)$ and 51 and above were 27(6.4\%).On level of 
education, $155(36.6 \%)$ of the respondents indicated that they are in the primary school and below, $123(29.1 \%)$ are attending secondary school, $78(18.4 \%)$ and $41(9.7 \%)$ are either attending or holding Polytechnic and University and 26(6.1\%)

Page | 3589 have no educational qualification. Most of the residents $121(28.6 \%)$ have stayed for less than 9 years while others have stayed $109(25.8 \%)$ above 9 years, 108(25.5\%) less than 3 years and $85(20.1 \%)$ less than 6 years, respectively. As for the distance between their houses or work place from the dumpsite, 159(37.6\%) were less than 3 houses apart, 120(28.4\%) were less than 6 houses apart, $107(25.3 \%)$ were more than 9 houses apart and $37(8.7 \%)$ were less than 9 houses apart (Table 1).

Table 2 shows the awareness on hazards/risk of parasitic infections associated with the dumpsite. Majority $370(87.5 \%)$ of the residents are aware that they are at risk of contracting human intestinal parasite for living close to the site, very few $14(3.3 \%)$ are not aware and 39(9.2\%) are not sure. Only $48(11.3 \%)$ responded that the highest hazard \risk they face for living close to the site was all the hazards listed in table 4.1.9, majority 413(97.6\%) responded to odour, 384(90.8) leachate water, $258(61.0 \%)$ litter, $225(53.2 \%)$ birds, $121(28.6 \%)$ pest and $113(26.7 \%)$ surface water contamination, while fire and smoke had the least responses of $48(11.3 \%)$ each. The residents $307(72.6 \%)$ were aware that waste from the site can breed flies, insects or worm that can cause intestinal parasites and $329(77.8 \%)$ believed that intestinal worms can be gotten from the site. About $304(71.9 \%)$ of the residents were aware that waste from the dumpsite can be washed into nearest water body causing intestinal worms to those that uses it.

The result on the Knowledge of residents, towards contacting intestinal parasites from solid waste dumpsites showed that $407(96.2 \%)$ have heard about it, $13(3.1 \%)$ have not and only $3(0.7 \%)$ are not sure if they've heard about it. About 59(|13.9\%) of all the residents agreed that it can be gotten through the means list in table 4.1. with majority
$365(86.3 \%)$ of them pointing at poor hygiene. Most of the residents $283(66.9 \%$ ) agreed that it has affected somebody in the family before, $111(26.2 \%)$ were not sure while 29(6.9\%) says it's no it has not. Majority 312(73.8\%) of the residents disclosed stomach ache as the symptoms of intestinal parasites while 301(71.2\%) disclosed vomiting, 298(70.4\%) diarrhea, 232(66.9\%) fever and $43(10.2 \%)$ don't know the symptoms of intestinal parasites. The greater percentage $329(77.8 \%)$ of the residents disclosed that one can get intestinal worms from the dumpsite, 53(12.5\%) responded no while $41(9.7 \%)$ are not sure about getting it from dumpsite (Table 3). When the residents were asked how one can get intestinal parasites from the dumpsite, $47(14.3 \%)$ of the residents agreed that it can be through all the means listed below in table 4, majority 319(97.0\%) of the residents responded by playing around the site, through leachate water at the site $317(96.4 \%)$ and through indiscriminate dumping of refuse in the site 302(91.8), only a few 47(14.3\%) responded through rats, rodents, snakes and other animals found around the site.

Residents attitude towards solid waste disposal at the site. Majority $385(91.0 \%)$ of the residents disposes waste at the dumpsite. Most 197(46.6\%) disposing it on a daily basis, $75(17.7 \%)$ twice a week, 62(14.7\%) once a week, 54(12.8) once in a while, and $28(6.6 \%)$ are not sure whereas a few others $7(1.7 \%)$ says it's thrice a week. Most of the respondent $320(75.7 \%)$ don't defecate at the site. About $47(11.1 \%)$ of the residents disclosed that intestinal parasites can be prevented through all the measures listed below with almost 419(99.1\%) all of them pointing at maintaining good hygiene as the most preventive measures followed by 417(98.9\%) avoiding leachate water in the site, $402(95.0 \%)$ properly disposing waste at the site, $329(77.8 \%)$ avoiding eating at the site while more of them $253(59.8 \%)$ says avoiding defecating around the site and 194(45.9\%) avoiding walking around the site on bare foot. Only a few of them $47(11.1 \%)$ 
responded to avoiding contact with insect, flies, rodents and other animals around the site. (Table 4)

Table 5 showed the residents awareness on waste management practices at the site. Most 222(52.5\%)

Page | 3590 of the residents $222(52.5 \%)$ are aware that clean environment are vital to their health while others $195(46.9 \%)$ are not aware that all waste are not unwanted and useless. Majority 312(73.8\%) agreed strongly that waste segregation at the site can reduce the amount of waste at the site. While some $216(51.1 \%)$ disagreed to the fact that waste at the site are managed regularly. Majority 312(75.9\%) agreed that the waste is used to fill the holes at the site. To them, it doesn't concern them if waste is managed regularly at the site or not. They are of the view that law should be put in place to guide waste disposal at the site and strongly disagreed that

Table 1: Socio-demographic characteristics of residents living close to a dumpsite in Aba municipal

\begin{tabular}{|c|c|c|}
\hline \multicolumn{3}{|c|}{ DEMOGRAPHIC INFORMATION } \\
\hline $\begin{array}{l}\text { Variable } \\
\text { Gender }\end{array}$ & No of Respondent & Percentage (\%) \\
\hline Male & 296 & $(70.0)$ \\
\hline Female & 127 & $(30.0)$ \\
\hline Total & 423 & $100 \%$ \\
\hline \multicolumn{3}{|l|}{ Age (years) } \\
\hline $0-10$ & 93 & $(22.0)$ \\
\hline $11-20$ & 103 & (24.3) \\
\hline $21-30$ & 84 & $(19.9)$ \\
\hline $31-40$ & 75 & (17.7) \\
\hline $41-50$ & 41 & $(9.7)$ \\
\hline 51 and above & 27 & (6.4) \\
\hline Total & 423 & $100 \%$ \\
\hline \multicolumn{3}{|l|}{ Educational background } \\
\hline No education & 26 & $(6.1)$ \\
\hline Primary education & 155 & $(36.6)$ \\
\hline Secondary education & 123 & (29.1) \\
\hline University & 41 & $(9.7)$ \\
\hline Polytechnics & 78 & (18.4) \\
\hline Total & 423 & $100 \%$ \\
\hline \multicolumn{3}{|l|}{ Length of stay in the area } \\
\hline Less than 3 years & 108 & $(25.5)$ \\
\hline Less than 6 years & 85 & $(20.1)$ \\
\hline Less than 9 years & 121 & $(28.6)$ \\
\hline Above 9 years & 109 & $(25.8)$ \\
\hline Total & 423 & $100 \%$ \\
\hline \multicolumn{3}{|c|}{ Distance of your house or work place from the dumpsite } \\
\hline Less than 3 houses apart & 159 & $(37.6)$ \\
\hline Less than 6 houses apart & 120 & $(28.4)$ \\
\hline Less than 9 houses apart & 37 & (8.7) \\
\hline More than 9 houses apart & 107 & $(25.3)$ \\
\hline Total & 423 & $100 \%$ \\
\hline
\end{tabular}

proper management of waste at the site will not make it a safer place for people. Some of the view that environmental policy for those living around the dumpsite is not necessary and that it doesn't matter how they dispose their waste at the site.

Majority of the respondents $78.6 \%$ believed that increased industrialization and consumption of fresh raw is the major factor militating against the level of efficiencies of Aba municipal, council in terms of waste management at the dumpsite, followed by material increasing population and lack of pollution control device $64.3 \%$ each while Poor enforcement of the waste management regulations is the least $7.1 \%$ factor militating against the level of efficiencies waste management at the site.(Table $6)$.

Table 2: Awareness on hazards/risk of parasitic infections associated with the

\begin{tabular}{ccc}
\hline CHARACTERISTICS & NO OF RESPONDENT & PERCENTAGE \\
& $\mathrm{N}=423$ & (\%) \\
\hline
\end{tabular}

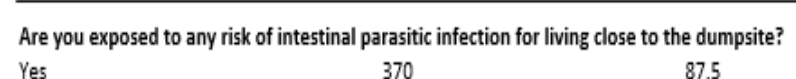

$\begin{array}{lll}\text { Yes } & 370 & 87.5 \\ \text { No } & 14 & 3.30 \\ \text { Not sure } & 39 & 9.2 \\ \text { Total } & 423 & 100\end{array}$

Which of these hazards/risks are you experiencing for staying close to the dumpsite? $\begin{array}{lll}\text { Odour } & 413 & 97.6\end{array}$ $\begin{array}{lll}\text { Fire } & 48 & 11.3\end{array}$

Smoke $48 \quad 11.3$

Pest(fly, rats and vermin) $\quad 121 \quad 28.6$

Birds $225 \quad 53.2$

litter $\quad 258 \quad 61.0$

Leachate (black liquid from dumpsite) $\quad 384 \quad 90.8$

$\begin{array}{lll}\text { Surface water contamination } & 113 & 26.7\end{array}$

All of the above $\quad 48 \quad 11.3$

None of the above 0

Total for each variable $\quad 423 \quad 100$

$\begin{array}{lcc}\text { Waste at the site can breed flies, insect or worms, which can cause intestinal parasites } \\ \text { Yes } & 307 & 72.6 \\ \text { No } & 81 & 19.1 \\ \text { Not sure } & 35 & 8.3 \\ \text { Total } & 423 & 100\end{array}$

Waste from the dumpsite can be washed into nearest water body such as waterside and cause intestinal worms to those that uses it

$\begin{array}{lll}\text { Yes } & 304 & 71.9 \\ \text { No } & 21 & 5.0 \\ \text { Not sure } & 98 & 23.2 \\ \text { Total } & 423 & 100\end{array}$


Table 3: Knowledge of the residents towards intestinal parasites from solid waste dumpsites.

Page | 3591

\begin{tabular}{|c|c|c|}
\hline CHARACTERISTICS & $\begin{array}{c}\text { NO OF RESPONDENT } \\
\qquad N=423\end{array}$ & $\begin{array}{c}\text { PERCENTAGE } \\
\text { (\%) }\end{array}$ \\
\hline \multicolumn{3}{|c|}{ HAVE YOU HEARD ABOUT INTESTINAL PARASITES OR WORMS? } \\
\hline Yes & 407 & 96.2 \\
\hline No & 13 & 3.1 \\
\hline Nat sure & 3 & 0.7 \\
\hline Total & 423 & 100 \\
\hline \multicolumn{3}{|l|}{ IF YES, HOW DO YOU GET IT? } \\
\hline Through under cooked meats and vegetables & 282 & 66.7 \\
\hline Insect bite & 59 & 13.9 \\
\hline Poor hygiene & 365 & 86.3 \\
\hline Bad habits such as walking around on bare foot & 213 & 50.4 \\
\hline Juju and witchcraft & 129 & 30.5 \\
\hline Animals such as rats, radents, vermin etc & 213 & 50.4 \\
\hline Food & 189 & 44.7 \\
\hline All of the above & 59 & 13.9 \\
\hline Nane of the above & 0 & 0 \\
\hline Total for each variable & 423 & 100 \\
\hline \multicolumn{3}{|c|}{ HAVE ANYBODY BEEN INFECTED WITH IT IN YOUR FAMILY BEFORE? } \\
\hline Yes & 283 & 66.9 \\
\hline No & 29 & 6.9 \\
\hline Not sure & 111 & 26.2 \\
\hline Total & 423 & 100 \\
\hline \multicolumn{3}{|c|}{ WHAT SYMPTOMS TELLS YOU THAT YOU HAVE A PARASITE IN YOUR BODY? } \\
\hline Fever & 232 & 66.9 \\
\hline Diarthea & 298 & 70.4 \\
\hline Vomiting & 301 & 71.2 \\
\hline Stomach ache & 312 & 73.8 \\
\hline I don't knaw & 43 & 10.2 \\
\hline All of the above & 0 & 0 \\
\hline Total for each variable & 423 & 100 \\
\hline \multicolumn{3}{|c|}{ CAN ONE GET INTESTINAL WORMS FROM SOLID WASTE DUMPSITE? } \\
\hline Yes & 329 & 77.8 \\
\hline No & 53 & 12.5 \\
\hline Nat sure & 41 & 9.7 \\
\hline Total & 423 & 100 \\
\hline \multicolumn{3}{|l|}{ IF YES, HOW CAN ONE GET IT FROM THE SITE? } \\
\hline By playing around the site & 319 & 97.0 \\
\hline Defecating at the site & 253 & 76.9 \\
\hline Walking around the site an bare foot & 194 & 59.0 \\
\hline Eating around the site & 172 & 52.3 \\
\hline \multicolumn{3}{|l|}{ Through rats, rodents, flies and other animals } \\
\hline found around the site & 47 & 14.3 \\
\hline Through leachate water at the site & 302 & 91.8 \\
\hline Indiscriminate dumping of refuse in the site & 317 & 96.4 \\
\hline All of the above & 47 & 14.3 \\
\hline Total for each variable & 423 & 100 \\
\hline
\end{tabular}

Table 4: Residents attitude towards solid waste disposal at the site

\begin{tabular}{lcc}
\hline CHARACTERISTICS & $\begin{array}{c}\text { NO OF RESPONDENT } \\
\mathrm{N}=423\end{array}$ & $\begin{array}{c}\text { PERCENTAGE } \\
(\%)\end{array}$ \\
\hline DO YOU DISPOSE WASTE AT THE DUMPSITE? & & \\
Yes & 385 & 91.0 \\
No & 38 & 9.0 \\
Not sure & 0 & 0 \\
Total & 423 & 100
\end{tabular}

HOW REGULAR DO YOU DISPOSE YOUR WASTE AT THE DUMPSITE?

Daily $197 \quad 46.6$

Once a week $\quad 62 \quad 14.7$

$\begin{array}{lll}\text { Twice a week } & 75 & 177\end{array}$

$\begin{array}{lll}\text { Thrice a week } & 7 & 1.7\end{array}$

Once in awhile $\quad 54 \quad 12.8$

Not sure $\quad 28 \quad 6.6$

$\begin{array}{lll}\text { Total } & 423 & 100\end{array}$

DO PEOPLE DEFECATE AT THE SITE?

$\begin{array}{lll}\text { Yes } & 65 & 15.4 \\ \text { No } & 320 & 75.7 \\ \text { Not sure } & 98 & 9.0 \\ \text { Total } & 423 & 100\end{array}$

HOW DO YOU PREVENT GETTING IT FROM THE SITE?

By avoiding defecating around the site $\quad 253 \quad 59.8$

Avoid eating at the site $\quad 329 \quad 77.8$

Avoiding the leachate water in the site $\quad 417 \quad 98.9$

Properly disposing waste at the site $\quad 402 \quad 95.0$

Avoiding contact with insects, flies, rodents and

other animals around the site $\quad 47 \quad 11.1$

Avoid walking around the site on bare foot $\quad 194 \quad 45.9$

Maintaining good hygiene $\quad 419 \quad 99.1$

All of the above $\quad 47 \quad 11.1$

None of the above 0

Total for each variable $\quad 423 \quad 100$


Table 5: Residents awareness on waste management practices at the site.

\begin{tabular}{|c|c|c|c|c|}
\hline $\begin{array}{l}\text { CHARACTERISTICS } \\
\mathrm{N}=423\end{array}$ & SA (96) & $A(96)$ & SD (\%) & D (76) \\
\hline $\begin{array}{l}\text { Having a clean environmental is vital to } \\
\text { health. }\end{array}$ & $222(52.5)$ & $126(29.8)$ & $41(9.7)$ & $34(8.0)$ \\
\hline All waste is unwanted and useless. & $57(13.5\}$ & $13\langle 3.1\rangle$ & $195(46.9)$ & $158(37.4)$ \\
\hline $\begin{array}{l}\text { Segregation of waste at the site helps to } \\
\text { reduce the amount of waste at the site. }\end{array}$ & $312(73.8)$ & $56\{13.2\}$ & $12(2.8)$ & $43\{10.2\}$ \\
\hline $\begin{array}{l}\text { The wastes at the site are managed } \\
\text { regularly. }\end{array}$ & $117(27.7)$ & $56\{13.2\}$ & $34(8.0)$ & $216(51.1)$ \\
\hline $\begin{array}{l}\text { Wastes at the site are used to fill the hole } \\
\text { in the land. }\end{array}$ & $321(75.9)$ & $75\{17.7\}$ & $B(19)$ & $19\{4.5\}$ \\
\hline $\begin{array}{l}\text { It concerns me if I see waste scattered } \\
\text { anywhere in the dumpsite area. }\end{array}$ & $22(5.2)$ & $47(11.1)$ & $192(45.4)$ & $162(38.3)$ \\
\hline $\begin{array}{l}\text { There should be rules and regulations } \\
\text { guiding waste disposal at the dumpsite. }\end{array}$ & $197(46.6)$ & $76\{18.0\}$ & $9 \mathrm{a}\{23.2\}$ & $52\{12.3\}$ \\
\hline $\begin{array}{l}\text { If waste is managed properly, the } \\
\text { dumpsite will be safe for people. }\end{array}$ & $113(26.7)$ & $106(25.1)$ & $124(29.3)$ & $\mathrm{BO}\{18.9\}$ \\
\hline $\begin{array}{l}\text { There should be environmental policy } \\
\text { for those living around the dumpsite. }\end{array}$ & $57(13.5)$ & $73\{17.3\}$ & $137(32.4)$ & $156(36.9)$ \\
\hline $\begin{array}{l}\text { It doesn't matter how I dispose my } \\
\text { waste at the site. }\end{array}$ & $52(12.3)$ & $78\{18.4\}$ & $143(33.8)$ & $150(35.5)$ \\
\hline
\end{tabular}

Table 6: Extent at which the following factors militate against the level of efficiency of waste management at the dumpsite.

\begin{tabular}{|c|c|c|c|c|}
\hline $\begin{array}{l}\text { Variable } \\
\qquad N=14\end{array}$ & High (96) & Moderate (\%) & Low (\%) & No (\%) \\
\hline Insufficient fund & $4(28.6)$ & $7(50.0)$ & $3(21.4)$ & $0(0)$ \\
\hline Inadequate trained personnel & $O(0)$ & $2[14.3)$ & $11(78.6)$ & $1(7.1)$ \\
\hline $\begin{array}{l}\text { No financial sacrifices for environmental } \\
\text { Protection }\end{array}$ & $5[35.7)$ & $7(50.0)$ & $1(7.1)$ & $1(7.1)$ \\
\hline Lack of proper education by the people & $6[42.9]$ & $7(50.0)$ & $1(7.1)$ & $0(0)$ \\
\hline Negligence of duty & $2(14.3)$ & $3\{21.4\}$ & $7(50.0)$ & $2[14.3]$ \\
\hline Increasing population & $9(64.3)$ & $5(35.7)$ & $O(0)$ & $0(0)$ \\
\hline $\begin{array}{l}\text { Lack of adequate awareness on the part of the } \\
\text { public on waste management }\end{array}$ & $\mathrm{B}[57.1]$ & $6[42.9]$ & o(0) & $O(0)$ \\
\hline Lack of pollution control devices & $9(64.3)$ & $5(35.7)$ & o(0) & $O(0)$ \\
\hline $\begin{array}{l}\text { Poor enforcement of the waste management } \\
\text { regulations }\end{array}$ & $1(7-1)$ & $2(14.3)$ & $\mathrm{B}[57.1]$ & $3[21.4]$ \\
\hline $\begin{array}{l}\text { Culture of the people seems not to respect human } \\
\text { dignity and decency }\end{array}$ & $4(28.6)$ & $6[42.9]$ & $1(7.1)$ & $3[21.4]$ \\
\hline $\begin{array}{l}\text { Increased industrialization and consumption of } \\
\text { fresh raw materials }\end{array}$ & $11(78.6)$ & $3(21.4)$ & $O(0)$ & $O(0)$ \\
\hline
\end{tabular}




\section{Discussion}

The number of respondents $370(87.5 \%)$ that are aware that they are at risk of contracting human intestinal parasitic infections for living close to the dumpsite is a clear indication of the existence of the infection. When asked about the hazards that they experience for staying close to the site, $48(11.8 \%)$ responded positively to all the hazards, but majority of them 413(97.6\%) agreed that odour was the most serious hazards experienced. This confirmed the finding of Aluko (2001) that people are aware of the offensive odours that emanate from refuse dumps and that they diminish the aesthetic quality of the environment. This also supported the insertion of Mirian (2011) in Delta State, who stated that waste left unattended to for a long time constitute serious hazards and produces offensive odour which can cause serious health challenges to those living around the site. In identifying the specific type of environmental problem, they are facing, $72.6 \%$ of the respondents' agreed that solid waste is a breeding ground for flies, insects or worms that can cause the intestinal parasite. This is in line with the report by Olaniran (1995) that the link between environment and health is fairly misunderstood by the average person in most developed and developing countries. The result indicated that most $(71.9 \%)$ of the respondents are aware that waste from the site can be washed into the nearest water body thereby causing intestinal parasitic infections to those that use it. In his study, Owoh (2000) also reported positive correlation with frequent contact with solid waste polluted river and incidence of water related diseases of which intestinal parasite infections were inclusive.

Majority of the respondents (77.8\%) have the knowledge that intestinal parasites can be contracted from the dumpsites. When they were asked how one can contract it from the site, $(14.3 \%)$ responded that it can be through all the means while $97.0 \%$ is of the view that it can be contracted by playing around the site, others says that is gotten from the leachate water at the site and the refuse dumped at the site. A good number of them $66.9 \%$ agreed that at least one member of their family has been previously infected with most $(73.8 \%)$ of them reporting stomach ache, diarrhea71.2\%, vomiting $70.4 \%$ and fever $66.9 \%$ as the symptoms of the infections. Onibokun and Kumuyi (1996) in South Africa ascertained that the knowledge about solid waste being the sources of transmission of diseases are supposed to be publicized as often as possible so that individuals at all levels will be aware of the effects of indiscriminate waste disposal.

Most of the residents (91.0\%) dispose waste at the site and almost half of the respondents dispose refuse on daily basis. Majority said specifically that it is gotten through poor hygiene and are aware that by maintaining good hygiene these diseases can be prevented. These are in consonance with the impression of Akpan (1995) in Calabar when he advised educationist to note that people know that their health is affected by the environment, and they sometimes know how to practice environmental hygiene.

The respondents strongly agreed that having a clean environment is vital to their health and strongly disagreed that all wastes are useless and unwanted. Also, most (73.8\%) individuals are aware that segregation of waste helps to reduce the amount of waste generated from the site but they strongly disagreed that waste management at the site is done regularly. This implied that there is improper management of waste at the site. Most of the individuals (75.9\%)are aware that the wastes at the site are used for landfilling. However, some disagreed strongly saying that it's not their concerns if they see waste scattered anywhere around the dumpsite. Although there are laws guiding environmental protection agency in Abia State, the respondents strongly believed that there should be rules and regulations guiding waste disposal at the dumpsite and few (29.3\%) 
strongly disagreed that the dumpsite will never be safe for people even when waste is properly managed. Uchegbu (2002) found that lack of sound judicial setup to try offenders tended to make the populace indifferent to the hues and Page | 3594 cries about waste management. However, few of the residents disagreed to the view that there should be environmental policy for those living around the dumpsite saying that it does not matter how they dispose waste at the site. This is in line with the suggestion of Achalu (1997) in Kaduna about waste management who suggested that social control is most effectively guaranteed by the exercise of individual and corporative selfdiscipline, not punitive legislation.

The major factor revealed by the dumpsite workers that militates against their level of efficiency in waste management was increased industrialization and consumption of fresh raw materials. Lack of pollution control devices and increasing population were the second most militating factors against the efficiency in waste management. This agreed with the findings of Attah and Schuller (2000) who found that high rate of population growth in the city of Dema and requirement of urban development resulted in an increase in the amount of human services which increased the amount of solid waste generation. Similarly, Zhu et al. (2008) ascertain that due to rapid urbanization, environmental sanitation problems are at the heart of the woes of African countries that the proliferation of urban population comes with its rising demand for food and other essential services which in turn increases the waste generated daily by each household. This contradicted the findings of Sule (2004) in Lagos which revealed labour related problems like low remuneration and inadequate equipment. Sampson -Akpan (2009) in Calabar ascertained that the problems and challenges of the current waste management process are these: scavengers unearth the disposed waste and remove useful materials for sale or recycling, inadequate equipment's, inability to maintain vehicles due to continuous use and wearing out of parts, lack of funds because waste management is a capital intensive project, rapid turn-over of workers because of exhaustion, body pains and offensive odour and compliance with safety precaution because workers do not feel comfortable wearing gloves, masks, boots and protective clothing because they feel clumsy. However, Yap (2010) in Kenya stated that the overall process of providing adequate universal sanitation, health and hygiene entailed a high degree of integration across disciplines but historically, the sanitation sector has been characterized by poor funding, fragmentation and disorganization.

\section{Conclusion}

It is glaring that people living close to solid waste dumpsites are not ignorant of the fact that human intestinal parasites can be contacted from solid waste dumpsites. The percentage of those that have had about intestinal parasites and the possibility of contracting it from solid waste dumpsite were relatively high. Most residents dispose waste at dumpsites on daily basis and maintain that waste management at the site should be carried out on a daily basis. The dumpsite workers revealed that increased industrialization and consumption of fresh raw materials, lack of pollution control devices and increasing population were the most militating factors against the efficiency in waste management at the site. Therefore, the government and relevant agencies should encourage municipality participation in sanitation improvement programmes. Intensify efforts in public health education and manage the waste generated. This will go a long way to reduce the risk of being infected with waste related diseases since the waste will not be left untreated for a long time as it used to be. 


\section{REFERENCES}

ABIA (STATE, NIGERIA) - POPULATION (2016) city population. de Retrieved. https://en.wikipedia.org/wiki/Aba, Abia\#cit e note-citypopulation-1

Achalu, F. O. (1997). Nigeria's environmental problems and current legislative controls: the Action Plan. Nigeria School of Health Journal, 9(1-2): 33 - 38.

Adewole, A. T. (2009) Waste management towards sustainable development in Nigeria: A

case study of Lagos state. International. NGO Journal, 4(4): 173-179.

Akpan, E.A (1995).Environmental Health Education. The Science of the Total Environment, 15: 1 - 10.

Attah, C. S. and Schullar, A. (2011) Assessment of factors influencing hygiene behavior among school children in Dema, Burkina Faso. BioMedical Central Public Health, 34(5): $12-23$.

Adeyeba, O. A. and Akinbo, J. A. (2002). Pathogenic intestinal parasites and bacterial agents in solid wastes. East African Medical Journal, 79(11): 600 - 603.

Amadi, A. N. (2012). Quality assessment of Aba river using heavy metal pollution index. American Journal of Environmental Engineering, 2(1): 45 - 49 .

Akinwale, A. (2005). Waste Management in Nigeria Local Governments. International Conference on Energy, Environment and Disasters 2005, Charlotte. Scientific Research, 24 - 30.

Akpan, E.A (1995).Environmental Health Education. The Science of the Total Environment, 15: 1 - 10.

Aluko, O. O. (2001). Characterization and treatment of leachates from a municipal solid waste landfill site in Ibadan, Journal for Parasitology, 18: 19 - 34.
Attah, C. S. and Schullar, A. (2011). Assessment of factors influencing hygiene behavior among school children in Dema, Burkina Faso.BioMedical Central Public Health, 34(5): $12-23$.

Bartone, C. R. (2000). Strategies for improving municipal solid waste management: Lessons from World Bank lending. Presentation at International workshop for planning of sustainable and integrated solid waste management. International Journal of Environmental Resource, 1(1): 28 - 34.

Basavanthappa, B. T. (2008). Community Health Nursing.2nd ed. Jaypee Brothers Medical Publishers, New Delhi, 234.

Bing X., Bloemhof J.M., Ramos T.R.P., BarbosaPovoa A.P., Wong C.Y., van der Vorst J.G.A.J. (2016) Research challenges in municipal solid waste logistics management. Waste Management .48:584-592.

Burges, H. J. (1982). Large scale management systems and parasite populations: Prevalence and resistance of parasitic agents in animal effluents and their potential hygiene hazards. Veterinary Parasitology, 11: $49-69$.

Cletus, I. I., Okoi, E. E., Stephen, C. E. and Atting, I. (2015) Parasitological Evaluation of UnDisposed Refuse Dumps in Calabar South, Crossriver State, Nigeria. International Journal of Pure and Applied Zoology, 3(3): $232-239$.

Drew, G., TarmerVestlund, A., Hough, R. L., Chackiath, S. J., Broomfied, M. and Longhurst, P. S. (2007). Health impart assessment of alternate week waste collection of bio degradable waste. Waste Management and Research Journal of the International Solid Waste Association, 34(5): $23-32$.

Emily, W., (2004). Municipal solid waste management in developing Countries.Journal of Applied Sciences and Environmental Management, 6(2): 78 - 83.

Etusim, P.E., Kalu, C., Nduka, F.O., Kalu, E.C., Melariri, P.E., Nwoke, M. and Aduaka, A.C. 
(2013) Studies on the Prevalence of Malaria Parasite among Children with Splenomegaly in Aba Metropolis, Abia State, Nigeria. Journal of Medical and Applied Biosciences 5(1): $56-66$.

Page | 3596 Glossary of Environment Statistics (2001). Preventing worker injuries and deaths from moving refuse collection vehicles. National Institute for Occupational Safety and Health, 23: 97 - 110.

Gupta N., Yadav K.K., Kumar V. A (2015) Review on current status of municipal solid waste management in India. Journal of Environmental Science (China). 37:206217.

Isa, A. A. A., (2006) Demographic; trends and human development in Nigeria. Commandant National War College Inaugural Lecture to Participants of NWC course 15, Abuja Nigeria. Journal of Policy Development Studies, 65(34): 12 - 34.

Loboka, M. K., Shihua, Q., Celestino, J. L., Hassan, S. O., and Wani, S. (2013). Municipal solid waste manangement and fecal coliform water contamination in the cities of the developing countries: the case of Juba, South Sudan. International Journal of Environmental Science, 3(5): 1614 - 1624.

Lou, Y. F and Nair, J. (2009). Safe management of wastes from health-care. Activities. Bioressouce Technology, 100: 3792 - 3798.

Mirian, O. I. (2011). Refuse disposal and its attendant health hazards: A Case Study of Agbor, Delta state of Nigeria. Global Journal of Environmental Sciences, 10(2): $12-32$.

Modebe, I. and Ezeama, N. N. (2011). Public health implication of household solid waste management in Awka South East Nigerian. The Journal of Public Health, 12(23): 1 - 11.

Obianyo, J. J. and Ugwu, E. I. (2018) Physiochemical and microbiological study of Aba River, Abia State, Nigeria. Umudike Journal of Engineering and Technology,4(1): 1 - 8 .
Okoronkwo, M. O. and Onwuliri, C. O. E. (1998). Intestinal parasites from refuse dumps and abattoir wastes in plateau State Nigeria.Journal of Medical Laboratory Science, $7: 25$ - 33.

Olaniran, N. S. (1995). Relationship on the environment to health. Environment and Health, 34(13): 112 - 119.

Onibokun, A. G. and Kumuyi, A. J. (1996). Urban poverty in Nigeria: Towards Sustainable Strategies for its Alleviation, Centre for African Settlement Studies and Development, Ibadan, Nigeria. Journal of Environmental Extension, 10:1 - 2.

Onyido, A. E., Okolo, P. O., Obiukwu, M. O. and Amadi, E. S. (2009). A Survey of vectors of public health diseases in un-disposed refuse dumps in Awka Town, Anambra State, South Easthern Nigeria. Research Journal of Parasitology, 4: 22 - 27.

Ovu, S. I., (2008). Introduction to Environmental Health, $2^{\text {nd }}$ ed, God Giveth Printing and publishing Company, Nigeria. 112.

Owoh, E. B. (2000) Clean up Nigerian boss speaks on waste management crsis in Lagos. Nature, $45-48$.

Prasad, B. A. (2013). Urban sanitation: Health Challenges of the Urban Poor. Research Journal of Family, Community and Consumer Sciences, 1(3): 1 - 6.

Samson -Akpan, P. E. (2009). Solid waste management in Calabar, Cross River State. International Journal of Social Sciences and Humanities Review, 2(2): 1 - 20.

Sida, E. D. (2012). Water and sanitation information brief no. 6. Department of International Organization and Policy Support, 2: $1-2$.

Staniskis, J. (2005). Integrated waste management: Concept and Implementation. Environmental Research, Engineering And Management, 3(33), 40 - 46.

Sule, R. O. (2004). The environmental consequences of rapid urbanization in 
countries of the developing world. Journal Environmental Studies, 2(1): 45 - 51.

Tchobanoglous, G., Karagiannidis, A., Leverenz, H., Cadji, M., and Antonopoulos, I. (2007). Sustainable waste management at special event using reusable dishware: example of whole earth festival at the university of California, Davis. Fresenius Environmental Bulletin, 15(8a), 822 - 828.

Uchegbu, S. N., (2002). Private systems of solid waste disposal: A Comparative Analysis of the Experiences in Umuahia and Owerri. Environmental Review, 4(1) 468 - 484.

United States Environmental Protection Agency (2013). Report on the 2013 U.S. Environmental Protection Agency (EPA),
International Decontamination Research and Development Conference. 600: 14-210.

Williams-Blangero, S. J. S., Upadhayay, R. P. and Manral, D. D. K. (1998). Attitude towards helminthes infections in Jirel population of Eastern Nepal. Social Science and Medicine, 47: 371 - 379.

Yap, J. (2010). Knowledge, attitudes and practices towards pandemic influenza sanitation and infrastructure branch, United Nations-Habitat. School of Public Health Digest, 1(1): 10 - 16.

Zhu, D., Asnani, P. H., Zurbrugg, C., Anapolsky, S. and Mani, S., (2008). Improving municipal solid waste management in India. Environment and Science, 12: 1 - 12. 